\title{
ESTUDO DO METABOLISMO E PRESERVAÇÃO DO SANGUE FRESCO E ESTOCADO TRATADO PELA VIOLETA DE GENCIANA.
}

A quimioprofilaxia da doença de Chagas transfusional - condição responsável pela infecção tripanossomótica de aproximadamente 20.000 novos casos anuais, no Brasil, ${ }^{1}$ iniciada por Pedreira de Freitas e cols ${ }^{4}$, contando atualmente com dezenas de experimentos e mais de 1000 substâncias testadas, continua tendo na violeta de genciana, preconizada por Nussenzweig e cols ${ }^{2}$, a sua principal arma ${ }^{3}$.

Com o objetivo de tentar definir a conveniência do emprego sistematizado da violeta de genciana na quimioprofilaxia da tripanossomiase cruzi, bem como, analisar as restriçōes à sua utilização, estudamos o metabolismo do eritrócito, em presença do referido sal, desde a coleta até o 28 . dia de estocagem.

Observamos que, o comportamento dos niveis de adenosina trifosfato (ATP) eritrocitário, foi semelhante ao controle até o $210^{\circ}$ dia, evidenciando queda significativa somente ao $28^{\circ}$ dia de estocagem. O 2.3 difosfo-glicerato (DPG) apresentou diferença significante aos $21 \%$ e $28 \%$ dias, porém com valores superiores ao minimo considerado como razoável a uma boa preservação ao final da 4a semana.

$\mathrm{O}$ pH, pressão parcial do oxigênio $\left(\mathrm{pO}_{2}\right)$, pressão parcial do gás carbônico $\left(\mathrm{pCO}_{2}\right)$, sódio e potássio, mostraram comportamentos semelhantes ao controle e a fragilidade osmótica evidenciou aumento significativamente menor que o controle, sugerindo maior resistência à hemólise.

Concluímos que o emprego da violeta de genciana na quimioprofilaxia da doença de Chagas transfusional, nas regiōes endêmicas e/ou que não disponham de reações sorológicas seguras para 0 diagnóstico desta tripanossomose, deve ser efetivamente estimulado.

\section{REFERÊNCIAS BIBLIOGRÁFICAS}

1. Dias JCP. Análise e perspectiva do controle da doença de Chagas no Brasil. Revista Brasileira de Malariologia e Doenças Tropicais 35:109-119, 1983.

2. Nussenzweig V, Sonntag R, Biancalana A, Pedreira de Freitas JL, Amato Neto V, Kloetzel J. Açào de corantes tri-fenil-metânicos sobre o Trypanosoma cruzi in vitro. Emprego da violeta de genciana na profilaxia da transmissão da moléstia de Chagas por transfusảo de sangue. O Hospital 44:731-744, 1953.

3. Organização Mundial da Saude - Special Programme for Research and Training in Tropical Diseases. Meeting on development on trypanocidal compounds for sterilisation of blood. Geneve, 13-14 December, 1984.

4. Pedreira de Freitas JL, Biancalana A, Amato Neto V. Nussenzweig V, Sonntag R. Barreto JG. Moléstia de Chagas em bancos de sangue na capital de São Paulo. $\mathrm{O}$ Hospital 41:229-283, 1952.

Helio Moraes de Souza

Faculdade de Medicina do Triangulo

Mineiro, Praça Manoel Terra s/n -

38100 Uberaba, MG. Brasil.

Recebido para publicaçào em 16/12/85. 